Active Remembering, Selective Forgetting,

and Collective Identity: The Case of Bloody Sunday*

Brian Conway

University of Notre Dame

IDENTITY: AN INTERNATIONAL JOURNAL OF THEORY AND RESEARCH 2003, 3 (4), 305-323

*The definitive version is available at http://www.leaonline.com/doi/abs/10.1207/S1532706XID0304_01?journalCode=id 


\begin{abstract}
Bloody Sunday, Derry, Northern Ireland, January 30, 1972, in which 13 Catholic civilians were shot dead by the British army has evoked two contesting memories - an 'official' or elite memory and a folk memory among the Nationalist community that, it is argued, has been omitted from dominant memory discourses. The official memory of this life-destroying historical event is encoded in the report of the Widgery Tribunal established by the British government in the aftermath of Bloody Sunday. A second popular memory has emerged in resistance to this that carries the remembrances of the victims' families and of the wider Nationalist community in Northern Ireland. I explore the mediums through which this unofficial memory has been established and maintained, the meanings associated with it, and how and why these have changed over time. Traditionally, it has been invested with a negative meaning associated with sectarianism, colonialism, and victimization. In recent times, the folk memory has been framed within a broader global context with a focus on its healing and reconciliation potential, which, together with institutional statements such as the Downing Street Declaration and the Good Friday Agreement, points to the emergence of a more inclusivist understanding of collective identity-formation in Northern Ireland.
\end{abstract}

Key Words: collective memory, commemoration, myth, meta-memory, Northern Ireland, identity 


\section{Active Remembering, Selective Forgetting, and Collective Identity: The Case of Bloody Sunday}

On the 30 January, $1972^{1}$, 13 people were shot dead by the British army while taking part in a peaceful civil rights march against the policy of internment ${ }^{2}$ in a predominantly Catholic area of Derry ${ }^{3}$ city, Northern Ireland, known as The Bogside. This event was a watershed in the history of 'The Troubles', the 30-year campaign of violence and murder carried out by loyalist and republican terrorists over competing claims to the territory that constitute the 6 counties of Northern Ireland.

The purpose of this paper is to consider the role of the collective memory of Bloody Sunday in the formation of group identity in Northern Ireland. In so doing, I apply some of the concepts, ideas and themes introduced by social psychologists and sociologists to this examination of social memory. The key question that I pose is this: what kind of memory of Bloody Sunday is being transmitted from one generation to the next ? Put another way, is the memory of Bloody Sunday, if it is possible to speak of a single shared memory of it at all, based on an inclusivist or exclusivist understanding of identity-formation?

The present paper is divided into six analytical components. It begins by situating Bloody Sunday within the context of 'The Troubles'. Second, the concept of memory is discussed. Third, I look at the renewal of scholarly interest in memory as an explanatory variable for understanding the construction of collective identity. Next, I examine how sociologists have theorized about memory and its relation to identity-formation. The substantive part of the paper explores the two memories of Bloody Sunday that, it is argued, form the memory matrix of this event - a folk or popular memory represented in 
street murals, granite monuments, and commemorative rituals in Derry and an official or institutionalized memory encoded in the report of the Widgery Tribunal ${ }^{5}$. The principal focus is on the former, the mediums through which it has been carried, the meanings associated with it, and how and why these have changed over time. Finally, I look at identity talk in institutional statements in Northern Ireland such as the Good Friday Agreement and the Downing Street Declaration that points to the emergence of an inclusive understanding of identity.

\section{Historical Background}

'The Troubles’ in Northern Ireland have a long, complicated and difficult history. Although it is often understood as a religious-based conflict, it is more complex than this (White, 2001). Its origins can be traced to the plantation of Ulster ${ }^{6}$ in the early 1600 s by English and Scottish settlers (Rose, 1971). From this period on, Irish Catholics were regarded as a subordinate group (Ó Dochartaigh, 1997). In the period 1800 to 1921, the island of Ireland was ruled from London under the Act of Union 1800. A Home Rule movement campaigned for and eventually won a modicum of independence with the advent of the Home Rule Act in 1914. However, World War I forced the suspension of the act. But the movement for Irish independence did not diminish. The Easter Rising of 1916 and the subsequent execution of all but one of its leaders strengthened the movement behind breaking the link with Westminister. In 1919, the first Irish parliament was established. It lent its support to a War of Independence, a guerilla war that took place between 1919-1921 and ended in a truce between the Irish Republican Army and the British forces in Ireland. Following this, negotiations began between the British 
government and the Irish which culminated in the Anglo-Irish Treaty of 1921. This treaty codified the partition of the island into a six-county Northern Ireland state and a twentysix county Irish Free State. (Walsh, 2000). But this treaty arguably brought more division than unity, causing a split and civil war between a pro-Treaty camp on the onehand and an anti-Treaty camp on the other, a fault line that defined the political terrain in the Irish Free State for several decades (White, 2001). From its birth in 1921, the Northern Ireland state was a sectarian society. The 1930s saw frequent rioting between Catholics and Protestants. In the policy arena, this was a period in which a welfare state apparatus began to take shape with cradle-to-grave provision (Hennessey, 1997). It was at this time also that Nationalists ${ }^{7}$ grew increasingly aggrieved with the Northern Ireland state as it felt shut out from public employment opportunities generated by welfare state expansion (Rose, 1971). Unionists became more alienated in turn from the Irish Free State because they saw it as a Catholic and clerical-dominated state. In their eyes, there was little to disconfirm the theory that 'Home Rule’ was ‘Rome Rule’ (Anderson et al, 2001). When World War II broke out, the Northern Ireland state turned its attention to the war effort. After the war, a program of social reform in the areas of education, public health, social services, and housing was restarted. Nationalists claimed that this welfarism favored Unionists while Nationalist grievances were disputed by the Unionist population (Hennessey, 2001). So by the late 1950s and early 1960s, the Northern Ireland state appeared as sectarian as it had been forty years previously.

The 1960s was a turbulent time in Northern Ireland and Derry city was the center of much of the conflict of this period. Deteriorating social and economic circumstances 
and the denial of basic civil rights provided the impetus for protest action by disaffected Catholics whose presence could be said to have been officially regarded as an anomaly in what was then a Protestant dominated state (Ó Dochartaigh, 1997). Catholics, in turn, came to view the Northern Ireland state as an oppressive and alien 'Protestant state for a Protestant people', in the words of James Craig, Northern Ireland's first Prime Minister. In addition, drawing on the experience of African-Americans in the civil rights movement in the United States, Catholics began to develop a critical consciousness and advocate more forcefully for their rights in housing ${ }^{8}$, employment, and civic life generally (Kirby et al, 2002; Kearney, 1997). Structural inequalities along religious lines were materialized most in local authority housing ${ }^{7}$ - if a Catholic was allocated a house by the local housing authority it invariably was the lowest standard one (Walsh, 2000). Group identity then was maintained and reinforced through the material conditions of the society (Woodward, 1997). That this occurred is not surprising given that Unionists ${ }^{8}$ viewed Catholics as disloyal to the Northern Ireland state (Ó Dochartaigh, 1997). Exclusion of Catholics from the social, economic and political life of the state, found expression on the streets of Northern Ireland through riots, protest marches, and other forms of collective action. One of the most prominent of these was the Northern Ireland Civil Rights Association formed in 1968. Using nonviolent means, it advocated for the extension of basic civil rights to the Catholic population.

Tension between the security forces and the Catholic community during this period was high. Faced with institutional threats to their identity, many aggrieved Catholics turned to the IRA's ${ }^{9}$ leadership to provide an anchor for it (Lee, 1989). As a 
result, support for the IRA grew in Catholic 'ghettos' such as the Bogside in Derry to the extent that these areas became 'no go' areas even for the British army and police. It was in this context that the British government decided to introduce internment ${ }^{5}$ in Northern Ireland and to step up security in Catholic neighborhoods. This policy further alienated the nationalist community (Ó Dochartaigh, 1997). Many anti-internment marches were organized in protest across Northern Ireland and one of these became the focus of an event that later was popularized in the collective memory in the name 'Bloody Sunday'.

On January 30, 1972, one of these internment marches took place in the city of Derry. In response, the Unionist community, led by Ian Paisley ${ }^{10}$, mobilized to hold a counter-march. The British government sensed that a dangerous confrontation was likely and so drafted in its elite Parachute Regiment to deal with the unfolding situation. Although the Unionist counter march was called off, the anti-internment march went ahead. It began in Creggan estate and its route would take it through the Bogside to Derry city center. When the march reached Free Derry Corner in the Bogside area of Derry city, a Catholic neighborhood, it took a turn for the worst. Within the space of a few minutes thirteen people were shot dead by the British paratroopers and another was seriously wounded. Many more were injured but did not die from their wounds. This event provoked a negative reaction across Northern Ireland, the Republic of Ireland, and the international community (Walsh, 2000). As a result, the British government came under pressure to establish what happened on this fateful day and in response set up the Widgery Tribunal chaired by Lord Widgery, a prominent English judge. This inquiry issued a swift report which exonerated the soldiers of any wrongdoing. Although it said 
that there was no evidence to show the civilians were armed, it suspected that they were. The soldiers that fired and shot dead the thirteen civilians claimed in evidence to the Widgery Tribunal that they were fired upon. However, forensic and other evidence showed that none of the civilians who were killed were carrying weapons or bombs (Walsh, 2000; Lee, 1989). Nonetheless, the content between the covers of the Widgery report, that has little in common with the folk memory, represents the official memory of Bloody Sunday to the present day.

Since 1972 the relatives of the civilians killed on Bloody Sunday have campaigned for an independent inquiry. In 1995, fresh new evidence that previously received little attention was found and evoked renewed interest in Bloody Sunday. The Irish government assembled this new evidence and presented it to the British government in the form of a report written by a legal scholar, Prof. Dermot Walsh. In response to this, the British Prime Minister, Tony Blair, announced the establishment of the Saville Tribunal of Inquiry ${ }^{11}$ in 1998 to revisit the events of Bloody Sunday (Walsh, 2000).

\section{Defining the Concept of Collective Memory}

As mentioned already, the concept of memory is increasingly used in both historical and sociological research, reflecting what Levy calls a "historical turn” (Levy, 1999). In this research, its meaning is somewhat elusive because of the fact that it is difficult to delineate the precise relationship between these phenomena: individual and collective memories, the past and the present, and what element of memory is internal and what is external (Kansteiner, 2002; Olick, 1999; Gedi and Elam, 1996; Middleton 
and Edwards, 1990). Some scholars argue that it is so vague and all-encompassing that it has little merit as a term while others contend that it sensitizes people to the influence of the social context on the formation of memory (Olick, 1999; Kansteiner, 2002; Zelizer, 1995; Middleton and Edwards, 1990). Still others contend that the term is merely old wine in a new bottle (Gedi and Elam, 1996). Nonetheless, two distinct but interrelated meanings are prominent in the literature. First, it refers to people's shared recollections of past events that they have had first-hand experience of (Hirsch, 1995). Events and moments of this kind are typically the most memorable (Schuman and Scott, 1989). The second meaning attached to it is the memories of the past that are embodied in genre or 'technologies of memory' such as films, books, documentaries, poems, songs, memoirs, and the like, that give a future, so to speak, to the past by allowing it to be transmitted from one generation to the next (Kansteiner, 2002). In the example of Bloody Sunday, the memory of it is immortalized in literature and in songs such as U2 (Irish rock band)'s 'Bloody Sunday’. Lipsitz argues that forms of memory such as television often provide an outlet for the expression of oppositional memories that are excluded from dominant narratives (Lipsitz, 1990). One form of memory then stems from direct lived experience of the past while the other is mediated through forms of popular culture or technologies of memory (Olick \& Robbins, 1998; Zelizer, 1995). The crucial point here is that individuals 'do remembering' while the content of memory comes from outside the individual, that is, from society (Olick, 1999). 


\section{The Renewal of Interest In Collective Memory}

There is a growing body of literature cutting across different disciplinary fields and societies on the memory or memories of various life-destroying historical events such as the Holocaust, the Vietnam War, the assassination of President John F. Kennedy, World War 1 and 2, September 11th, and Bloody Sunday, that reflects the increasing importance of and attention to the concept (Nerone and Wartella, 1989; Levy, 1999;

Olick, 1999; Kammen, 1995; Gedi and Elam, 1996; Zelizer, 1995; Vinitzky-Seroussi, 2002; Gergen, 1991; Gillis, 1994; Middleton and Edwards, 1990). I do not claim that these events are identical. Each of these life-denying and traumatic events is different, to be sure, in terms of their nature, the number of lives lost and their ramifications but all, nonetheless, are arguably important cases in one way or another for understanding processes in the development of collective memory. The renewed interest in collective memory and particularly that of negative or traumatic as opposed to triumphal events owes something to the rise of multiculturalism and postmodernism as well as the politics of victimization and regret (Olick \& Robbins, 1998; Olick, 1999; Kammen, 1995; Wagner-Pacifici and Schwartz, 1991). Nora (1989) states, "we speak so much of memory because there is so little of it left” (p.1). That memory loses its mythic power over time, there is little doubt. As a people, we are just as inclined to forget about the past, often in selective ways, as we are to remember it (Epstein and Lefkovitz, 2001). Memory, as Nora observes, is always and everywhere "subject to the dialectic of remembering and forgetting”, suddenly and gradually (McBride, 2001, p.11). 
The renewal of interest in collective memory also holds true in Ireland. In this context, McBride (2001) writes:

In Ireland, perhaps more than in other cultures, collective groups have expressed their values and assumptions through their representations of the past. There is no evidence, moreover, that this preoccupation is abating; if anything, questions of collective memory and commemoration have assumed a new prominence in recent years (p.3)

Indeed, without a capacity to remember it is difficult to see how culture could survive at all. Culture, after all, is a people enacting or telling a story and the stories we share with one another carry our memories forward within them from one generation to another through socialization (Epstein, 2001; Zerubavel, 1996). The next section of the paper looks at how sociologists have thought and written about memory and the two complementary processes that make it possible - remembering and, its dialectical partner, forgetting (Andrews, 1991).

\section{Collective Memory and Identity}

Sociologists view memory as a key locus of identity-formation. Memory, they argue, is embodied in us as part of who we are (Middleton and Edwards, 1990). Put another way, people’s representations of the past are a window onto their identity. By identity-formation I mean the process by which individuals develop and sustain a sense of self in and through the social groups to which they belong (Jussim et al, 2001; Middleton and Edwards, 1990). Key identity questions include “who am I?”, “who are we?”, “who are they?” (McAdam et al, 2001). In addition, sociologists argue that 
memory is manifestly social and intersubjective in two senses: (1) representations of the past are preserved through social practices such as commemoration rituals (2) memory is created in interaction between and among people in the small group, community, and societal contexts (Schwartz, 1982; Schwartz, 1991; McBride, 2001; Olick \& Robbins, 1998; Andrews, 1991; Zerubavel, 1996; Connerton, 1989; Bakhurst, 1990).

Language concretizes events within these social settings (De Cillia, Reisigl, and Wodak, 1999; Kansteiner, 2002; Howard, 2000; Middleton and Edwards, 1990). When we see an event such as the shooting dead of a civilian we categorize and name it in accordance with our culturally-created classification schema (Zerubavel, 1997). Language thus helps us to grasp and make sense of the world and attach meaning to it (Coser, 1992, p.168). But language, as Halbwachs notes, “presupposes not just one person but a group of associated persons” (Coser, 1992, p.170). Not every Nationalist or Unionist in Northern Ireland took part in the events of Bloody Sunday. Not every Nationalist or Unionist was a witness to it either. But many people, both nationalist and loyalist, remember that day as a watershed moment even though they were not there in person. Whether they saw the events on television or mediated through others by word of mouth, they remembered Bloody Sunday as participants in a community of memory (Zerubavel, 1997, p.90).

Individuals also have their own unique perspective and memories and some people's memories are qualitatively different to others. In addition, we can have memories that we share with some but not others (Zerubavel, 1996). To say that memory 
is socially and culturally situated is not to deny that it has a psychological dimension unique to the autonomous self. Halbwach argues that "to be sure, everyone has a capacity for memory that is unlike that of anyone else.....but individual memory is nevertheless a part or an aspect of group memory......to the extent that it is connected with the thoughts that come to us from the social milieu (family, church, community organizations, political parties, neighborhoods, ethnic groups etc.)” (Coser, 1992, p.53). In addition, as well as remembering as participants in mnemonic communities, these communities are themselves defined by processes of shared remembering (Olick, 1999; Zerubavel, 1996).

Collective and individual memory, then, are inter-related, that is, much of an individual's memory is culturally constructed and at the same time social memory is mediated through individual memory (Nerone, 1989; Olick, 1999). In addition, we can say that although we can share certain memories with others, not everyone remembers the past in the same way. In otherwords, the past is not a monolithic mass. To some extent how we read the past depends on where we sit, that is, on perspectivity. Thus, for example, the Catholic residents who took part in the civil rights march have a very different memory of what happened than the memory recorded in the Widgery Report.

The act of remembering goes on inside our heads but not independently of the social relations of which we are a part. What we remember and what we forget is to a greater or lesser extent shaped by the social environment in which we are embedded (Andrews, 1991; Zerubavel, 1996). The term 'collective memory' suggests that remembering is a social phenomenon to the extent that we share with others the 
memories they hold of significant events, happenings, and people in their lives. We are, as MacCurtain puts it, a “memory-carrying people” (Falconer and Liechty, 1998, p.104). One of the important consequences of this culturally constructed and socially shared conception of memory is that the past is not a given. Rather, it is continually reinterpreted, reevaluated, and re-membered often in the light of factors related to the present (Andrews, 1991; Zerubavel, 1996). Connerton argues that it is difficult to disentangle the past from the present because, as he puts it, "present factors tend to influence - some might want to say distort - our recollections of the past, but also because past factors tend to influence, or distort, our experience of the present” (Connerton, 1989, p.2). Not everyone is equally powerful in their ability to claim and define the past. What gets defined as the "official” memory reflects the power of certain groups in society to define the past according to their present needs, inclinations and interests often by silencing alternative and competing memory discourses (De Cillia, Reisigl, and Wodak, 1999; Middleton and Edwards, 1990). The result is that the same past is claimed by different social groups in different and sometimes contradictory ways.

What then is the relationship of memory to identity-formation understood here as the process by which people create and sustain their identity ? Sociologists argue that memory is part of our identity tool-kit, defining our present sense of self and our relation to the Other (Lipsitz, 1990; Levi, 1995; Epstein, 2001). Identities then, at an individual and collective level, are created and sustained by memory. Put another way, memory is part of the cultural repertoire that we draw on to make sense of reality and our place in it which, in turn, influences our attitudes and behavior (Hirsch, 1995). Identity is not, 
however, created in a vacuum. Rather, it is constructed in a political and social environment in which objective markers of identity such as religion, gender, and ethnicity are invested with subjective meanings through social interaction that reflect a society's power relations and ideologies (Hirsch, 1995; Middleton and Edwards, 1990). Sociological theorizing about identity then leads to the following propositions: memory is a central component of identity and biography; identity and memory are socially constructed and reconstructed; identity arises from self-other interaction; the self emerges over time and place; narratives or stories carry memories forward from one historical period to another thus reproducing society's ties to the past; stories define our present identities; identity in turn defines what is remembered and what is forgotten about the past (Weigert, 1997; Michener and DeLamater, 1999; Epstein, 2001; Lipsitz, 1990; Gillis, 1994; Connerton, 1989).

In the case of Northern Ireland, the identity category of Protestant was historically ranked above Catholic and this became the basis for the way the state acted towards and treated the Catholic population. Thus the subordinate position of Catholics became normalized in the Northern Ireland state. This in turn influenced how Catholics perceived their own identity and how the state perceived itself. Collective identity then is dialogic, that is, the other defines the self (Kiberd, 1996). Unwilling to view the Northern Ireland state or the regime that coordinated it as legitimate, Catholics defined their identity in opposition to the identity of Protestants thus creating a social world of two opposing identity categories of 'us' and 'them' (Kirby et al, 2002; Kearney, 1997; White, 2001; Rose, 1971). This binary opposition created an environment in which each viewed the 
other as a threat to its identity and this in turn provided a rationalization for violence and terrorism against the Other (Hirsch, 1995; Staub, 2001; White, 2001). Participation in violence or being a victim of it in turn became part of the socialization process of both traditions and influenced how each conceived their identity. Traumatic events like Bloody Sunday, as they became stamped on their memory bank, became the lens through which people think about themselves - their past, goals and ideals - and orient their behavior toward the Other (Nerone and Wartella, 1989). The construction of national identity then has to do with delineating one's group from what the group is not, that is, with the creation of 'in-groups’ and ‘out-groups’ (De Cillia, Reisigl, and Wodak, 1999; Woodward, 1997). And one way a group can delineate itself from another is through its understanding of the past.

\section{Contesting Memories}

Representations of the past are not always shared. Indeed, "mnemonic battles” over the 'proper' way to remember past events are increasingly common (Zerubavel, 1996; Koonz, 1994; Wagner-Pacifici and Schwartz, 1991). Because memories of the past are an important mechanism through which people create and validate individual and collective identity, contests around memory and commemoration are tied to the meanings different people attach to particular events in the past (Hirsch, 1995; Zerubavel, 1996). This leads to a puzzle or dilemma posed by Wagner-Pacifici and Schwartz, that is, the difficulty of commemorating a past about which there is no consensus (Wagner-Pacifici and Schwartz, 1991). 
In this context, Gillis argues that there is nothing automatic about commemoration (Gillis, 1994). In the case of Bloody Sunday, there was no "Bloody Sunday day” to commemorate the event. Denied a state-approved form of commemoration and a voice in narrating the “official” memory of January 30, 1972, Nationalists in the Bogside area of Derry told the myth ${ }^{12}$ of Bloody Sunday through lieux de memoire, as Nora put it, or sites of memory that include, among other things, street murals in housing estates and a granite monument as a memorial to the dead. Murals are important in two respects as commemorative objects - their use of color (in stark contrast to the gray of traditional granite monuments) and their appeal to the visual senses (Nic Craith, 2002). Two of these murals are particularly significant. One portrays the handkerchief-waving Fr Edward Daly (later Catholic Bishop of Derry ${ }^{13}$ ) guiding a cadre of civilians through the streets of the Bogside to safety, an image that stands out perhaps more than any other as a symbol of Bloody Sunday. This mural privileges the Nationalist narrative of Bloody Sunday over the other principal social actor within it - the Northern Ireland state - and in so doing validates its identity as an oppressed social group.

A second mural is also noteworthy as a site of memory that locates people in their past (Clark, 2001). Portraying mug-shot images of the victims, all Catholic males ranging in age from seventeen to fifty-three, it brings into reality the life-destroying effect of Bloody Sunday. It puts a name and a face on the victims and in so doing lays claim to their memory and to the fact that they remain part of the identity of the individuals and groups they belonged to (Staub, 2001; Sherman, 1994). These murals illustrate the use of space in the service of commemoration and how it helps people not to allow their 
individual and collective memories to fall victim to one of the basic and fundamental threats to memory, that is, amnesia (Zelizer, 1995).

Apart from the mural paintings, the people of Derry commemorate the events of January 1972 at the annual commemoration ritual. This event has become a time for retelling the story (Gillis, 1994). Significantly, this year is the $30^{\text {th }}$ anniversary of Bloody Sunday and in honor of it, a permanent memorial to the victims was dedicated by Dr Edward Daly, retired Catholic Bishop of Derry. The permanent memorial consists of a granite monument with the names of the victims listed on it. In addition, it alerts people to why they died by stating they "were murdered by British paratroopers” although this is clearly at odds with the official memory. Wearing the same clerical stole he wore on Bloody Sunday, Bishop Daly said that he hoped the memory of the victims and their struggle for justice and civil rights would not fall victim to forgetfulness. He said that the theme of the $30^{\text {th }}$ anniversary commemoration was identification with all victims of injustice the world over, whether on the basis of race, religion or nation. Further, he stated that a new plague unveiled at the dedication was in honor of "all those who have struggled, suffered and lost their lives in the pursuit of liberty, justice and civil rights”. In the past, in contrast, the recurring motif of the annual commemoration was sectarianism and division. In 1997, the Deputy Leader of Sinn Fein ${ }^{14}$, Martin McGuinneas ${ }^{15}$, speaking at the annual commemoration, for instance, said that Bloody Sunday represented a "wound" in the past and that as long as it remained so it would not be forgotten. In saying this he was acknowledging that the past is imprinted in people's mental life and that it shapes their consciousness in the present (Schudson, 1989). He went on to say, drawing 
on familiar Republican scripts, that "it was as if the British put us on a rollar coaster of

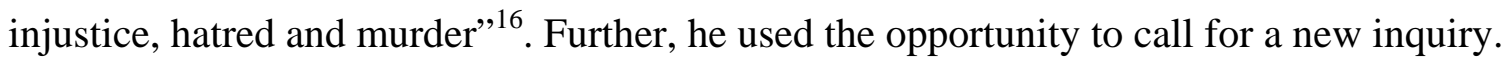
However, the tone and meanings associated with the commemoration have changed over time (Spillman, 1997, p.6).

Consider, for instance, that the $30^{\text {th }}$ anniversary ${ }^{17}$ was marked by a special program of events that included, the unveiling of a 'Remembering Quilt' and the holding of a discussion forum on 'Myth Making and Collective Memory'. The theme of the anniversary was ‘One World, Many Struggles’ which hinted at Northern Ireland’s shared experience with other troubled places in the world and the globalization of identity-based conflicts. Now the emphasis in the discourse, texts, and images associated with Bloody Sunday is on the potential for healing, reconciliation and unity created by the events of January $30^{\text {th }}, 1972$. This theme is represented in a poster of the $30^{\text {th }}$ anniversary which shows a picture of a small globe in the place of the center of an orange flower set against a background depicting a peaceful march. Past commemoration posters ${ }^{18}$, in contrast, highlighted the bloody in 'Bloody Sunday’ by using, for instance, imagery of a bloodstained map of Ireland. Others used funeral imagery to evoke the deaths of the victims and one poster for the $11^{\text {th }}$ anniversary carries the blunt message 'civil order, plastic death'. The focus was clearly more exclusive, narrow and sectarian with appeals to conquest, oppression, and colonialism. In short, there was no attempt to frame the memory in global terms and to sensitize people to a linked fate with injustices across the world (Adam, 1999). How can this redefinition of the collective folk memory be understood ? Is it an acknowledgement and acceptance by the ordinary residents of the 
Bogside of the state's unwillingness to accept criminal guilt for the event ? Does it invite the attention of other people in the virtual absence of recognition by the state of the collective folk memory ? In recent times, the mainstreaming of Bloody Sunday as a human rights issue linked to other human rights struggles in the world points to the globalization of its memory and its common cause with other life-destroying events in troubled places. Further, it reflects the global reach of a human rights ethic in which there is a sense of universal guilt for traumatic past events, a sense that humankind is responsible for dark moments in its history (Hirsch, 1995). This framing in terms of an international theme that is developed through poster images and reinforced through discourse emphasizing healing and reconciliation, it is argued represents an important reworking of the memory of Bloody Sunday and more specifically a movement away from the enemy-making 'us' versus 'them' motif of the past towards a more inclusivist understanding of identity-formation. Spillman argues that the international world order plays a significant role in validating the construction of national identity. In this sense, talk about the world and its location in it, adds strength to a group's claims to a certain interpretation of its past (Spillman, 1997). Further, it reflects the internationalization of 'the Irish question' in recent years and the rejection of the notion that it is an internal problem to be dealt with by the British government alone (Kearney, 1997; White, 2001).

\section{Back to the Future}

The human struggle over remembering Bloody Sunday, I claim, is part of a larger struggle in Northern Ireland to move away from a sectarian society defined along the fault lines of nationalism on the onehand and unionism on the other, towards a society 
undergirded by an inclusivist or universal identity that gives equal respect or parity of esteem, in peace process discourse, to both traditions. Recent institutional statements in Northern Ireland hold promise for a better future in Northern Ireland in this respect. Indeed, it could be that the increasing cooperation between the islands of Ireland, North and South, as reflected in the development of new North-South or all-Ireland institutions in areas such as tourism, has encouraged an awareness of the importance of coming to terms with blackspots in their histories.

In the Downing Street Declaration ${ }^{19}$, a document that laid the foundation for the current Northern Ireland 'peace process', the British and Irish governments together emphasized the importance of not sanitizing or succumbing to the past, and by extension the memory of it. Consider, for instance, the following excerpt:

The Taoiseach, Mr. Albert Reynolds, TD, and the Prime Minister, the Rt. Hon. John Major, MP, acknowledge that the most urgent and important issue facing the people of Ireland, North and South, and the British and Irish Governments together, is to remove the causes of conflict, to overcome the legacy of history and to heal the divisions which have resulted, recognizing that the absence of a lasting and satisfactory settlement of relationships between the peoples of both islands has contributed to continuing tragedy and suffering

Later this is followed by some inclusivist identity talk:

The role of the British Government will be to encourage, facilitate and enable the achievement of such agreement over a period through a process of dialogue and cooperation based on full respect for the rights and identities of both traditions in 
Ireland. The British and Irish Governments will seek, along with the Northern Ireland constitutional parties through a process of political dialogue, to create institutions and structures which, while respecting the diversity of the people of Ireland, would enable them to work together in all areas of common interest. The Good Friday Agreement ${ }^{20}$ is underpined by an inclusivist understanding of identity: Whatever choice is freely exercised by a majority of the people of Northern Ireland, the power of the sovereign government with jurisdiction there shall be exercised with rigorous impartiality on behalf of all the people in the diversity of their identities and traditions and shall be founded on the principles of full respect for, and equality of, civil, political, social and cultural rights, of freedom from discrimination for all citizens, and of parity of esteem and of just and equal treatment for the identity, ethos, and aspirations of both communities.

Memory can be a potential oppressor as well as a potential liberator (Kammen, 1995; Zelizer, 1995). It has something of an ambivalent nature to it potentially undergirding both inclusivist and exclusivist understandings of group identity-formation (Weigert, 1991). Venkatesh writes that "any formally available source of information can never document a history defined by contest, resistance......it is personal and collective memory that must be tilled with rigor and then matched against the formal record" (Venkatesh, 2000 p.11). This matching process is now taking place through the Saville Inquiry. As I write, its work of memory-making is in progress. The future will tell how successful it will be in helping to create a new third memory, a meta-memory of Bloody Sunday. Indeed, it could well be that only now, 30 years on, in the context of the Northern Ireland peace process and the climate of openness, dialogue and reconciliation that has stemmed 
from it, that the project of creating a meta-memory that does justice to the varied and conflicting understandings of the past can be achieved.

\section{Conclusion}

In this paper I argue that the human struggle over the memory of Bloody Sunday and the competition for hegemony between the folk memory on the onehand and the official memory on the other was the acting out of a wider struggle about the legitimacy of the identity associated with the Northern Ireland state. I argued that Bloody Sunday, as one single event in the history of 'the Troubles' in Northern Ireland, grew out of a sectarian society that was founded on an exclusivist understanding of identity in the sense that the political system was tilted in favor of the material interests of the Unionist population. In this context, the Northern Ireland state found itself attempting to construct a master narrative for a society composed of people with oppositional identities (Dietler, 1998). Within this narrative it is argued that representation of Bloody Sunday among the Nationalist community was not given the attention it might have been. Thus the initial folk memory that emerged to contest the official narrating of Bloody Sunday and to make the Nationalist community's memory the basis of the identity of the Northern Ireland state put emphasis on this event as an example of state oppression and domination. Later it was reframed with a focus on the shared experience of Bloody Sunday with other struggles against injustice in the world.

The principal lesson that can be drawn from this analysis in terms of understanding other similar events is that although people materialize their memories of 
traumatic historical events in murals, monuments, and memory quilts, these sites of memory are themselves subject to change as people come to new understandings of their symbolic meaning and thus construct and reconstruct new identities and memories. It offers a hopeful message that these new memories that represent the past can be used as a tool to bring about peace and reconciliation in troubled places and aid in the process of fashioning a more peaceful, just, and democratic future. 


\section{References}

Adam, H. (1999). Divided Memories: Confronting the Crimes of Previous Regimes.

Telos. 31, 87-108.

Anderson, B. (1991). Imagined Communities: Reflections on the Origins and Spread of Nationalism. London: Verso.

Andrews, M. (1991). Lifetimes of commitment: Aging, politics, psychology. Cambridge: Cambridge University Press.

Bakhurst, D. (1990). Social Memory in Soviet Thought. In Middleton, D. and Edwards, D. Collective Remembering (pp.203-226). London: Sage.

Brow, J. (1990). Notes on Community, Hegemony, and the Uses of the Past. Anthropological Quarterly, 63 (1), 1-6.

Clark, P. (2001). Murals as Monuments: Students’ Ideas about Depictions of 'Civilization’ in British Columbia. Centre for the Study of Historical Consciousness, University of British Columbia, Vancouver, B.C. http://www.cshc.ubc.ca

Connerton, P. (1989). How societies remember. Cambridge: Cambridge University Press.

Corcoran, F. (2000). Technologies of Memory. In E. Slater and M Peillon (Eds.), Memories of the Present: A Sociological Chronicle of Ireland, 1997-1998 (pp.25-34).

Dublin, Ireland: Institute of Public Administration.

Coser, L.A. (Ed.). (1992). Maurice Halbwachs on Collective Memory. Chicago: The University of Chicago Press.

De Cillia, R., Reisigl, M., and Wodak, R.(1999). The discursive construction of national identities. Discourse and Society. 10,2:149-173. 
Dieter, M. (1998). A Tale of Three Sites: The Monumentalization of Celtic Oppida and the Politics of Collective Memory and Identity. World Archaeology. 30,1,72-89.

Epstein, J. and Lefkovitz, L.H. (2001). “Introduction: Shaping Losses, Cultural Memory, and the Holocaust. In Epstein, J. \& Lefkovitz, L.H. (Eds.). Shaping Losses: Cultural Memory and the Holocaust (pp.1-12). Chicago: University of Illinois Press.

Epstein, J. (2001). Remember to Forget: The Problem of Traumatic Cultural Memory. In Epstein, J. \& Lefkovitz, L.H. (Eds.). Shaping Losses: Cultural Memory and the Holocaust (pp.186-204). Chicago: University of Illinois Press.

Falconer, A. \& Liechty, J. (1998). Reconciling Memories. Dublin, Ireland: The Columba Press.

Farr, R.M. (1998). From Collective to Social Representations: Aller et Retour. Culture and Psychology, 4 (3), 275-296.

Garvin, T. (1996). 1922 The Birth of Irish Democracy. Dublin: Gill and Macmillan. Gedi, N. and Elam, Y. 1996. Collective Memory - What Is It? History and Memory. 8,1: 30-50.

Gergen, K.J. (1991). The Saturated Self. New York: Basic Books.

Gibbons, L. (2001). 'Where Wolfe Tone’s statue was not': Joyce, monuments and memory. In I. McBride (Ed.), History and Memory in Modern Ireland (pp.139-159). Cambridge, England: Cambridge University Press.

Gibbons, L. (1997). Doing Justice to the Past: The Great Famine and Cultural Memory. In Hayden T. (Ed.), Irish Hunger: Personal Reflections On The Legacy Of The Famine (pp.258-270). Dublin, Ireland: Wolfhound Press. 
Gibbons, L. (1998). History without the Talking Cure: Bloody Sunday as "Modern Event”. In Trisha Ziff. (Ed.), Hidden Truths: Bloody Sunday 1972 (pp.101-109). Santa Monica: Smart Art Press.

Gillis, J. R. (ed.). (1994). Commemorations: The Politics of National Identity. Princeton, New Jersey: Princeton University Press.

Hall, S. (Ed.). (1997). Representation: Cultural Representations and Signifying Practices. London, England: Sage.

Hennessey, T. (1997). A History of Northern Ireland 1920 -1996. Dublin: Gill and Macmillan.

Hirsch, H. (1995). Genocide and the Politics of Memory: Studying Death to Preserve Life. Chapel Hill, North Carolina: The University of North Carolina Press.

Howard, J. A. (2000). Social Psychology of Identities. Annual Review of Sociology. 26:367-393.

Jussim, L., Ashmore, R., Wilder, D. (2001). Introduction: Social Identity and Intergroup

Conflict. In Ashmore, R.D., Jussim, L., and Wilder, D. (Eds.), Social Identity, Intergroup Conflict, and Conflict Resolution, (pp.3-14). Oxford: Oxford University Press.

Kammen, M. (1995). “Review of Frames of Remembrance: The Dynamics of Collective Memory, by Iwona Irwin-Zarecka”. History and Theory. 34,3:245-261.

Kansteiner, W. (2002). Finding Meaning in Memory: A Methodological Critique of Collective Memory Studies. History and Theory. 41, 179-197.

Kearney, R. (1997). Postnationalist Ireland: politics, culture, philosophy. London: Routledge. 
Kiberd, D. (1996). Inventing Ireland: The Literature of the Modern Nation. London:

Vintage.

Kirby, P., Gibbons, L., and Cronin, M. (2002). Reinventing Ireland: Culture, Society, and the Global Economy. London: Pluto Press.

Klein, K. L. (2000). On the Emergence of Memory in Historical Discourse.

Representations. 69:127-144.

Koonz, C. (1994). Between Memory and Oblivion: Concentration Camps in German Memory. In Gillis, J. (Ed.), Commemorations: The Politics of National Identity (pp.258280). Princeton, New Jersey: Princeton University Press.

Lee, J. (1989). Ireland 1912-1985: Politics and Society. Cambridge: Cambridge University Press.

Leerssen, J. (2001). Monument and trauma: varieties of remembrance. In I. McBride (Ed.), History and Memory in Modern Ireland (pp.204-223). Cambridge, England: Cambridge University Press.

Levi, P. (1995). Recording Memory and Teaching Humanity. In H. Hirsch, Genocide and the Politics of Memory: Studying Death to Preserve Life. Chapel Hill: The University of California Press.

Levy, D. (1999). The Future of the Past: Historiographical Disputes And Competing Memories In Germany and Israel. History and Theory. 38,1: 51-66.

Lipsitz, G. (1990). Time Passages: Collective Memory and American Popular Culture. Minneapolis: University of Minnesota Press.

Lorey, D. E. and Beezley, W. H. (2002). Genocide, Collective Violence, and Popular Memory. Wilmington, Delaware: Scholarly Resources. 
Marten-Finnis, S. (1995). Collective Memory and National Identities. Communist and Post-Communist Studies. 28,2:255-261.

McAdam, D., Tarrow, S., and Tilly, C. (2001). Dynamics of Contention. Cambridge:

Cambridge University Press.

McBride, I. (2001). History and Memory in Modern Ireland. Cambridge, England:

Cambridge University Press.

McKittrick, D. (1994). Endgame: The Search for Peace in Northern Ireland. Belfast, Northern Ireland: The Blackstaff Press.

McRedmond, L.(1996). Modern Irish Lives: Dictionary of $20^{\text {th }}$-century biography.

Dublin: Gill and Macmillan.

Michener, H.A. and DeLamater, J.D. (1999). Social Psychology. New York: Harcourt Brace.

Middleton, D. and Edwards, D. (Eds.). (1990). Collective Remembering. London: Sage. Mullan, D. (Ed.). (1997). Eyewitness Bloody Sunday: The Truth. Dublin, Ireland:

Wolfhound Press.

Nerone, J. and Wartella, E. (1989). Introduction: Studying Social Memory.

Communication. 11, 85-88.

Nerone, J. (1989). Professional History and Social Memory. Communication. 11, 89-104.

Nic Craith, M. (2002). Plural Identities - Singular Narratives: The Case of Northern Ireland. New York: Berghahn.

Nora, P. (1989). Between Memory and History: Les Lieux de Memoire. Representations, 26, 7-25. 
O’Carroll, P. (2000). Re-membering 1798. In E. Slater and M Peillon (Eds.), Memories of the Present: A Sociological Chronicle of Ireland, 1997-1998 (pp.15-24). Dublin, Ireland: Institute of Public Administration.

Ó Dochartaigh, N. (1997). From Civil Rights to Armalites: Derry and the Birth of the Irish Troubles. Cork: Cork University Press.

Olick, J. K. and Robbins, J. (1998). Social Memory Studies: From “Collective Memory” to the Historical Sociology of Mnemonic Practices. Annual Review of Sociology, 24, 105140.

Olick, J. K. (1999). Collective Memory: The Two Cultures. Sociological Theory. 17,3: 333-348.

Rose, R. (1971). Governing without Consensus: An Irish Perspective. Boston: Beacon Press.

Schuman, H., and Scott, J. (1989). Generations and Collective Memories. American Sociological Review. 54, 3, 359-381.

Schudson, M. (1989). The Present in the Past versus the Past in the Present. Communication. 11, 105-113.

Schwartz, B. (1991). Social Change and Collective Memory: The Democratization of George Washington. American Sociological Review, 56, April, 221-236.

Schwartz, B. (1982). The Social Context of Commemoration: A Study in Collective Memory. Social Forces, 61, 375-402.

Sicher, E.. The Past in the Present: Countermemory and Postmemory in Contemporary American Post-Holocaust Narratives.1-36. http://muse.jhu.edu/journals/ history_and_memory /v012/12.2sicher.pdf 
Sherman, D.J. (1994). Art, Commerce, And The Production Of Memory In France After World War I. In Gillis, J.R. (Ed.), Commemorations: The Politics of National Identity (pp.186-211). Princeton, New Jersey: Princeton University Press.

Slater, E. and Peillon, M. (Eds.) (2000). Memories of the Present: A Sociological Chronicle of Ireland, 1997-1998, Dublin, Ireland: Institute of Public Administration. Spillman, L. (1997). Nation and Commemoration: Creating national identities in the United States and America. New York: Cambridge University Press.

Staub, E. (2001). Individual and Group Identities in Genocide and Mass Killing. In R.D.

Ashmore, L. Jussim, and D. Wilder (Eds.), Social Identity, Intergroup Conflict, and Conflict Resolution (pp.159-183). New York: Oxford University Press.

Venkatesh, S.A. (2000). American Project: The Rise and Fall of a Modern Ghetto. Cambridge: Harvard University Press.

Vinitzky-Seroussi, V. (2002). Commemorating A Difficult Past: Yitzhak Rabin’s Memorials. American Sociological Review. 67:30-51.

Walsh, D. (2000). Bloody Sunday and the Rule of Law in Northern Ireland. Dublin, Ireland: Gill and Macmillan.

Weigert, A. (1991). Mixed Emotions: Certain Steps Toward Understanding Ambivalence. New York: State University of New York.

Weigert, A. (1999). Self, Interaction, and Natural Environment. Albany, New York: State University of New York Press.

Wagner-Pacifici, R. and Schwartz, B. (1991). The Vietnam Veterans Memorial:

Commemorating a Difficult Past. American Journal of Sociology, 97(2), 376-420. 
White, R. (2001). Social and Role Identities and Political Violence: Identity as a Window on Violence in Northern Ireland. In R.D. Ashmore, L. Jussim, and D. Wilder (Eds.), Social Identity, Intergroup Conflict, and Conflict Resolution (pp.159-183). New York: Oxford University Press.

Woodward, K. (1997). Identity and Difference. London: Sage and Open University Press. Zelizer, B. (1992). Covering the Body: The Kennedy Assassination, the Media, and the Shaping of Collective Memory. Chicago: The University of Chicago Press.

Zelizer, B. (1995). Reading the Past Against the Grain: The Shape of Memory Studies. Critical Studies in Mass Communication. 12:214-239.

Zerubavel, E. (1997). Social Mindscapes: An Invitation to Cognitive Sociology. Cambridge: Harvard University Press.

Zerubavel, E. (1996). Social Memories: Steps to a Sociology of the Past. Qualitative Sociology. 19,3 :283-299. 


\section{Footnotes}

${ }^{1} 2002$ is the $30^{\text {th }}$ anniversary of Bloody Sunday. It is disputed who fired the first shot. The Widgery Report concluded “it was entirely satisfied that the first firing in the courtyard was directed at the soldiers” (Walsh, 2000, p.102). However, no evidence that the civilians who were killed were carrying weapons was furnished in the report (Lee, 1989). The report went out to say that that the soldiers' evidence to the Tribunal could only have been true given the rigor of the questioning they faced - "if the soldiers are wrong they were parties to a lying conspiracy which must have come to light in the rigorous cross-examination to which they were subject” (Walsh, 2000, p.102).

${ }^{2}$ Internment refers to the policy of arresting and imprisoning people without trial suspected of involvement in terrorist activities.

${ }^{3}$ The "correct" name of (London) Derry is disputed. Derry is the gaelic word for oak wood (Rose, 1971). Among Nationalists, Republicans (a term which refers to Sinn Féin, the IRA, the Continuity IRA, the INLA (Irish National Liberation Army) and other variants of the IRA), and in the Republic of Ireland, Derry is the preferred name of the city. However, it has also been known as Londonderry, the preferred name of the city among Unionists and Protestants. Indeed, the contested nomenclature of the city reflects the religious and political divisions in it (Walsh, 2000).

4The term 'The Troubles' is used in popular and media discourse as a shorthand or euphemism denoting the Northern Ireland conflict.

${ }^{5}$ The Widgery Tribunal was established by the British government in the aftermath of Bloody Sunday. Its terms of reference were to inquire into "a definite matter of urgent 
public importance namely the events on Sunday 30 January which led to the loss of life in connection with the procession in Londonderry on that day” (Walsh, 2000).

${ }^{6}$ Ulster is the northern most province in the island of Ireland. The island of Ireland is composed of four provinces - Leinster, Connaught, Munster, and Ulster - and thirty-two counties. Twenty-six counties in the south make up the Republic of Ireland and sixcounties in the north make up Northern Ireland.

${ }^{7}$ In popular discourse, the terms Nationalist and Catholic are interchangeable. A Nationalist, broadly construed, refers to people who aspire to a united Ireland, that is, a thirty-two county state and the withdrawal of the British presence in Northern Ireland. It is a shorthand for anti-Britishness (Garvin, 1996, p.11). The great majority of Catholics in Northern Ireland are Nationalists. Similarly, the terms Unionist, Loyalist, and Protestant are more or less interchangeable. Unionism refers to a strain of political thought favoring Northern Ireland's union with the United Kingdom and loyalty to the British crown (Kearney, 1997, p.25). Furthermore, Unionists aspire to complete political separation from the Republic of Ireland. Followers of this political ideology are known as Unionists or Loyalists.

${ }^{8}$ The presence of systematic institutional discrimination on religious grounds in the allocation of council or public housing is disputed. Rose argues that there is little or no empirical evidence to support the institutional discrimination argument (Rose, 1971). However, one incident crystallizes the perceived sense of relative deprivation experienced by Catholics. In 1968, Austin Currie, a Nationalist MP, organized a 'squat in' in a house allocated by the Unionist-dominated local housing authority to a 19 year 
old, lone parent Protestant over a Catholic family living in unfit accommodation (Rose, 1971).

${ }^{8}$ In popular discourse, the terms Nationalist and Catholic are interchangeable. A Nationalist, broadly construed, refers to people who aspire to a united Ireland, that is, a thirty-two county state and the withdrawal of the British presence in Northern Ireland. It is a shorthand for anti-Britishness (Garvin, 1996, p.11). The great majority of Catholics in Northern Ireland are Nationalists. Similarly, the terms Unionist, Loyalist, and Protestant are more or less interchangeable. Unionism refers to a strain of political thought favoring Northern Ireland's union with the United Kingdom and loyalty to the British crown (Kearney, 1997, p.25). Furthermore, Unionists aspire to complete political separation from the Republic of Ireland. Followers of this political ideology are known as Unionists or Loyalists.

${ }^{9}$ The IRA is a republican paramilitary organization whose goal is a United Ireland pursued through violent means in the name of 'the people of Ireland' (Rose, 1971). Republican refers to Sinn Fein, the IRA, the Continuity IRA, the INLA (Irish National Liberation Army) and other variants of the IRA that represent a non-democratic and violent movement. Republicans are sometimes described as 'physical force' nationalists as opposed to 'constitutional' nationalists that use democratic means to achieve their aspirations.

${ }^{10}$ Rev Ian Paisley is the founder and current leader of the Democratic Unionist Party or DUP. Described by Lee as a "Protestant fundamentalist”, he was a key agitator against Nationalist participation in the political life of Northern Ireland from the 1960s on which he saw as leading to a United Ireland (Lee, 1989, p.423). He opposed power-sharing with 
Nationalists and sought to bring down an experiment in power-sharing between Unionists and Nationalists set up under the terms of the Sunningdale Agreement (1974). In 1951, he established the Free Presbyterian Church of Ulster in Northern Ireland. Throughout his political career, he has maintained a strong anti-Nationalist position and has come to be associated with a particularly hard-line form of Unionism or "rabid anti-Catholicism” as Lee put it (Lee, 1989, p.427). Within the Unionist community, he has lost support in recent times to more mainstream Unionists represented by the Ulster Unionist Party (UUP). The UUP supports the current Northern Ireland peace process while the DUP sees it as tilting towards the interests of Nationalists (McRedmond, 1996).

${ }^{11}$ The Saville Tribunal of Inquiry has its own website: http://www.bloody-sundayinquiry.org.uk/. Announcing the establishment of the inquiry in the House of Commons, January 28, 1998, the British Prime Minister, Tony Blair, stated that, “the time scale within which Lord Widgery produced his report meant that he was not able to consider all the evidence that might have been available”. Its terms of reference are to inquire into a “definite matter of urgent public importance, namely the events of Sunday, 30 January 1972 which led to the loss of life in connection with the procession in Londonderry on that day, taking account of any new information relevant to events on that day”.

${ }^{12}$ Myth refers to "the way things are as people in a particular society believe them to be; and they are the models people refer to when they try to understand their world and its behavior. Myths are the patterns - of behavior, belief, and of perception which people have in common” (Hirsh, 1995, p.25). Myth is related to the notion of ideology because ideology shapes what is remembered and forgotten and what elements of the past get 
commemorated. Ideology denotes "the patterns of beliefs and practices in society which ensure the reproduction of power relations” (Middleton and Edwards, 1990, p.61). ${ }^{13}$ Bishop Edward Daly, then a Catholic curate (priest) in the Bogside, Derry, played a central role in shepherding civilians out of the line of fire on Bloody Sunday. He was also instrumental in the campaign to establish a fresh inquiry. Along with the then Bishop of Clonfert, Dr Joseph Cassidy, and the then Bishop of Down and Connor, Dr Cahal Daly, he was a member of the delegation of the Irish Episcopal Conference to the New Ireland Forum (1983-1984) that was established to find ways of bringing about lasting peace in Northern Ireland. A strong critic of the IRA (Irish Republican Army), he wrote an autobiography, Mister, Are You A Priest?, describing his life up to his appointment as Catholic Bishop of Derry in 1974, including his first-hand experiences of Bloody Sunday. In January 2002, he led the rededication of the permanent memorial to the victims on the $30^{\text {th }}$ anniversary of Bloody Sunday (Source: Grogan, D. 2002. “Dr Daly leads Derry’s remembrance of dead”. The Irish Times, January 31, p.9).

${ }^{14}$ Sinn Féin, the Gaelic words for 'Ourselves Alone', is the political wing of the Irish Republican Army or IRA. The IRA is a republican paramilitary organization whose goal is a United Ireland pursued through violent means. In August 1994, the IRA announced a permanent cessation of its terrorist campaign and in so doing pledged its support for the current Northern Ireland peace process.

${ }^{15}$ Martin McGuinness is the deputy leader of Sinn Fein and current Minister for Education in the Northern Ireland Executive. A former IRA activist, he acted as Sinn Fein's chief negotiator in the multi-party talks that led to the Good Friday Agreement. In evidence to the Saville Inquiry, he stated that he was second-in-command of the IRA on 
Bloody Sunday, the first time he publicly acknowledged his involvement in the IRA. In addition, he stated that any weapons the IRA had at the time were not present in the Bogside on Bloody Sunday.

${ }^{16}$ Source: http://www.serve.com/pfc/weekly/inu4feb97.html\#Bloody

${ }^{17}$ Source: http://www.bloodysundaytrust.org/2002Programme.htm

${ }^{18}$ Source: http://cain.ulst.ac.uk/images/posters/bsunday/

${ }^{19}$ Source:http://www.irlgov.ie/iveagh/angloirish/jointdeclaration/default.htm

The Downing Street Declaration was signed between the then British Prime Minister, John Major, and the then Irish Taoiseach (Prime Minister), Albert Reynolds, on

December 15, 1993, as the foundation of the current Northern Ireland peace process. This declaration endorses the principal of consent, that is, that the future status of Northern Ireland would be determined by a majority of the people of Northern Ireland. It also makes a commitment to "remove the causes" of the Northern Ireland conflict and to the exclusive use of democratic peaceful means to achieve this.

${ }^{20}$ Source:http://www.gov.ie/iveagh/angloirish/goodfriday/default.htm

The Good Friday Agreement refers to the agreement between the major political parties in Northern Ireland reached on Good Friday, April 1998, following multi-party talks in Stormont Castle chaired by United States Senator George Mitchell who was appointed by President Bill Clinton to help broker between an agreement between the political parties in Northern Ireland. The agreement was endorsed in referendums in Northern Ireland and the Republic of Ireland. Among the issues agreed was the establishment of new NorthSouth institutions, a Northern Ireland Assembly or parliament, the holding of a referendum to remove the Republic of Ireland's constitutional claim to Northern Ireland, 
reforms in policing, decommissioning of paramilitary weapons, and reforms in the area of human rights and equality. 
